\title{
La Question du Home Rule écossais, 1880-1914
}

The Question of Scottish Home Rule, 1880-1914

\section{Christian Auer}

\section{OpenEdition}

\section{Journals}

Édition électronique

URL : http://journals.openedition.org/rfcb/3869

DOI : $10.4000 /$ rfcb.3869

ISSN : 2429-4373

Éditeur

CRECIB - Centre de recherche et d'études en civilisation britannique

\section{Référence électronique}

Christian Auer, "La Question du Home Rule écossais, 1880-1914», Revue Française de Civilisation Britannique [En ligne], XXIV-2 | 2019, mis en ligne le 19 juin 2019, consulté le 09 juillet 2019. URL : http://journals.openedition.org/rfcb/3869; DOI : 10.4000/rfcb.3869

Ce document a été généré automatiquement le 9 juillet 2019.

Revue française de civilisation britannique est mis à disposition selon les termes de la licence Creative Commons Attribution - Pas d'Utilisation Commerciale - Pas de Modification 4.0 International. 


\section{La Question du Home Rule écossais, 1880-1914}

The Question of Scottish Home Rule, 1880-1914

Christian Auer

\section{Introduction}

Avant d'examiner la question spécifique du Home Rule écossais, cet article donnera quelques éléments d'information sur le contexte politique de l'Ecosse de la fin du XIX siècle, notamment sa place au sein de l'Union et de l'Empire et la domination du parti libéral. Seront ensuite étudiées les associations qui se constituèrent à la fin du siècle pour obtenir la création d'un parlement spécifique pour l'Écosse, la Scottish Home Rule Association et la Young Scots' Society. La partie centrale de cet article sera consacrée à l'étude des débats qui se déroulèrent à la Chambre des communes sur le Home Rule écossais entre 1889 et 1914. Ces débats constituent, en effet, une remarquable source d'information sur la nature des arguments qui furent avancés en faveur du Home Rule. Pourquoi le Home Rule fut il proposé à ce moment-là? Quelle fut l'importance du sentiment nationaliste écossais dans les revendications en faveur du Home Rule? Quels furent les contours du dispositif proposé ? Comment les Home Rulers envisagèrent-ils la coexistence d'un parlement impérial et de parlements nationaux? Quels furent les arguments et contre-arguments développés par les partisans et les opposants au Home Rule? Les pages qui suivent auront comme objectif de fournir des éléments de réponses à ces quelques questions avant de proposer des hypothèses sur les raisons de l'échec du Home Rule écossais. 


\section{L'Écosse à l'époque victorienne}

\section{L'Union harmonieuse}

2 L'Écosse du XIXe siècle se caractérise en grande partie par une absence de revendications nationales qui peut s'expliquer par la relative autonomie dont elle bénéficiait depuis la loi sur l'Union de 1707. Celle-ci avait, certes, fusionné les parlements écossais et anglais en un unique parlement de Grande-Bretagne mais elle avait permis à l'Écosse de conserver sa religion, son système d'enseignement, son droit civil et son système judiciaire. Les interventions du gouvernement dans les affaires écossaises étaient très limitées, ce qui fait que les élites politiques et économiques bénéficiaient d'une grande marge de manœuvre pour gérer les affaires écossaises comme bon leur semblait. Cette quasiautonomie politique a été remarquablement décrite par Tom Devine : " For almost all of the nineteenth century, de facto Scottish political and administrative autonomy continued, with Westminster de jure sovereign but government delegated to Scottish institutions run by Scots $»{ }^{1}$

3 L'Union avait également permis aux Écossais de prendre une part active au développement de l'Empire. Les dizaines de milliers d'Écossais qui participaient à l'aventure impériale, que ce soit en tant que missionnaires, soldats, fonctionnaires, industriels ou marchands, assumaient avec fierté leur double identité d'Écossais et de Britanniques. Les Écossais considéraient d'ailleurs que c'était grâce à leur contribution que l'Empire avait pu atteindre un tel niveau de développement. De nombreux ouvrages mettaient en avant le rôle capital des Écossais dans des secteurs aussi variés que l'éducation, la religion, la médecine ou la philosophie ${ }^{2}$. La perception de l'Écossais comme bâtisseur d'empire devait, d'ailleurs, perdurer au début du XXe siècle. Dans son ouvrage publié en 1930, Andrew Dewar Gibb, professeur de droit à l'université de Glasgow et dirigeant du Scottish National Party de 1936 à 1940, insista sur la place fondamentale des Écossais au sein de l'empire :

The position of Scotland as a Mother-nation of the Empire is at all costs to be preserved to her. England and Scotland occupy a unique position as the begetters and the defenders of Empire. They alone of all the Aryan peoples in it have never been otherwise than sovereign and independent. Ireland and Wales, mere satrapies of England, can claim no comparable place. Scotsmen to-day are occupying positions both eminent and humble throughout that Empire, and Scottish interests are bound up with every colony in it.

Mentionner l'Écosse du XIX ${ }^{e}$ siècle ne peut donc se faire sans la dissocier de son appartenance à la Grande-Bretagne et son ancrage dans l'Empire.

L'absence de revendication nationaliste ne fut pas, pour autant, synonyme d'une mise entre parenthèses de la scotticité. L'Écosse victorienne se caractérisa également par un renforcement de la prise de conscience du caractère national, en particulier par le biais de références aux épisodes les plus marquants du passé écossais. On pense ici en particulier à la monumentale histoire de l'Écosse de Patrick Fraser Tytler publiée à partir de 1828 ou encore aux nombreux articles traitant de l'histoire écossaise publiés par la presse et notamment le People's Journal de Dundee, journal qui se vendait à plus de cent trente mille exemplaires en 1875. Cette réactualisation du passé se manifesta, entre autres, par la glorification de certaines des grandes figures historiques écossaises, comme Robert Burns, Robert Bruce ou encore William Wallace. Le culte de Wallace connut son apogée au XIX ${ }^{e}$ siècle et se manifesta notamment par la construction de monuments 
érigés en son honneur, dont le National Wallace Monument inauguré en 1869. Wallace était perçu comme celui qui avait permis à l'Écosse d'entrer dans l'Union sur un pied d'égalité avec l'Angleterre. Cette vision positive de l'Union était encore très présente dans le discours écossais du début du $\mathrm{XX}^{\mathrm{e}}$ siècle : c'est ainsi que Richard Lodge, professeur d'histoire à l'université d'Edimbourg, écrivit que l'Union n'avait en rien porté préjudice au sentiment national écossais. Le commentaire qui suit est d'autant plus intéressant qu'il date de 1907, époque à laquelle le mouvement en faveur du Home Rule écossais se manifestait:

At its origin [it was] illogical, and will probably be illogical at the end. It may well be that this is the secret of its success ... [for] the Union has satisfied Scotland only

because it has permitted the conservation of Scottish nationality. ${ }^{4}$

La National Association for the Vindication of Scottish Rights, fondée en 1853, témoigne, cependant, du fait que certains Écossais ne se satisfaisaient pas de la place de leur nation au sein de l'Union. L'Association considérait que l'Écosse était négligée par rapport à l'Irlande et que le nombre de députés écossais était largement insuffisant. La priorité pour ses membres était d'améliorer le système existant mais non pas d'y mettre un terme. La NAVSR eut beaucoup de peine à s'imposer dans le paysage politique écossais et sa dissolution trois ans plus tard, en 1856, confirme la faiblesse du nationalisme politique écossais à cette période.

\section{L'hégémonie du parti libéral en Écosse}

7 Les libéraux exercèrent un pouvoir sans partage en Écosse pendant la période victorienne. Alors qu'en Angleterre les conservateurs remportèrent six des sept élections législatives entre 1886 et 1914, ils ne remportèrent qu'une seule élection en Écosse, celle de 1900. Alors que le parti conservateur était perçu comme un parti figé, les libéraux incarnaient les valeurs de progrès, de réforme et de liberté, valeurs essentielles aux yeux des Écossais. Les Écossais manifestèrent une admiration sans réserve pour l'une des plus éminentes figures politiques de l'époque, William Gladstone, lui-même d'origine écossaise, parlementaire depuis 1833 mais élu dans la circonscription écossaise de Midlothian en 1880. Lors de la campagne de 1879, les électeurs écossais réservèrent un accueil triomphal à celui qui était perçu comme le représentant du libéralisme, "l'évangile politique " ${ }^{5}$ de la grande majorité des Écossais à l'époque. L'adoption du deuxième Reform Act de 1867, qui augmenta le nombre de sièges pour l'Écosse, renforça l'hégémonie du parti libéral : lors des élections de 1868, les libéraux obtinrent 52 des 60 sièges écossais. Leur domination commença à être contestée à la fin du XIX siècle, notamment après le troisième Reform Act de 1884 (le nombre de députés écossais passa à 72), qui étendit le droit de vote et augmenta la représentation des grandes villes. Ces modifications entraînèrent des dissensions entre la partie plus traditionnelle du parti libéral et les radicaux, encouragés par le soutien d'un nombre croissant de citoyens qui jusqu'alors avaient été privés du droit de vote. Certains de ces nouveaux électeurs considéraient le parti libéral comme le parti des forces capitalistes et du libre-échange destiné à promouvoir les intérêts d'une minorité de citoyens. En 1885, les libéraux radicaux écossais créèrent la National Liberal Federation of Scotland dont les objectifs prioritaires étaient de promouvoir une réforme de la Chambre des Lords et de mettre un terme au statut officiel de l'Église d'Écosse. 
8 La question du Home Rule irlandais constitua un autre point de discorde majeur au sein des libéraux écossais et mit à mal l'unité du parti libéral. Certains estimèrent que le Home Rule constituait une illustration parfaite de la dérive du parti vers des politiques trop réformistes; d'autres y voyaient une menace contre l'empire et le libre-échange; certains, enfin, considéraient que la politique du Home Rule démontrait que le parti avait cédé aux éléments les plus radicaux. Ces tensions ne firent que s'aggraver au fil des années et résultèrent en une scission officialisée par la création du Liberal Unionist Party qui, lors des élections de 1886, obtint un succès important en Écosse. L'année 1886 marqua donc la fin de l'hégémonie du parti libéral sur la vie politique écossaise. L'avance des libéraux sur les conservateurs ne cessa de se réduire pour aboutir, en 1900, à la première victoire en Écosse depuis 1831 des conservateurs, alliés au Liberal Unionist Party. Cependant, le revers électoral de 1900 ne saurait être interprété comme le déclin du parti libéral: lors du scrutin de 1906, les libéraux obtinrent une victoire écrasante en remportant 58 des 72 sièges en Écosse, succès confirmé lors des deux élections de 1910 alors que dans le reste du pays les conservateurs alliés aux Libéraux Unionistes faisaient pratiquement jeu égal avec les libéraux. L'idéologie libérale continua donc à régner en Écosse. C'est dans ce contexte politique particulier qu'émergea la question du Home Rule écossais.

\section{Le Home Rule écossais}

La question des modifications à apporter à l'architecture constitutionnelle du RoyaumeUni commença à devenir essentielle pour le parti libéral au cours des années 1870. Lors de la campagne électorale pour les élections législatives de 1880, William Gladstone, s'adressant à plusieurs milliers de personnes venues l'écouter à Dalkeith, précisa les raisons qui l'incitaient à penser qu'il était temps de modifier en profondeur le système parlementaire :

I intensely desire to see Parliament relieved of some portion of its duties. [...] We have got an overweight Parliament: and if Ireland, or any other portion of the country, is desirous and able so to arrange its affairs that by taking the local part of some local part of its transactions off the hands of Parliament, it can liberate and strengthen Parliament for imperial concerns, I say I will not only accord a reluctant assent, but I will give a zealous support to any such scheme. One limit, gentlemen, one limit only, I know to the extension of local government. It is this: nothing can be done, in my opinion, by any wise statesman or right-minded Briton to weaken or compromise the authority of the Imperial parliament [...] but subject to that limitation, if we can make arrangements under which Ireland, Scotland, Wales, portions of England can deal with questions of local and special interest to themselves more efficiently than Parliament now can, that, I say, will be the attainment of a great national good. ${ }^{6}$

10 Les partis politiques en Écosse adoptèrent des positions très différentes par rapport à la question du Home Rule. Les conservateurs s'opposèrent avec virulence à ce qu'ils percevaient comme une tentative de déstabilisation de l'Union et leurs interventions lors des débats parlementaires confirment qu'il leur était impossible d'imaginer un tel bouleversement constitutionnel. Le parti libéral se prononça de façon officielle pour le Home Rule écossais lors de son congrès annuel de 1888 : " The National Conference is of the opinion that Home Rule should be granted to Scotland, so that the Scottish people could have the sole control and management of their own National Affairs $» .^{7}$ Les libéraux écossais, comme cela a été évoqué précédemment, étaient divisés sur la question, même si une majorité 
d'entre eux soutinrent le Home Rule, certains jouant même un rôle important dans la création de la Scottish Home Rule Association. Le Labour écossais en fit une de ses revendications principales. Ramsay Macdonald et Keir Hardie, personnalités éminentes du Labour, furent membres de la Scottish Home Rule Association. Ramsay Macdonald fut à l'origine de la création du London General Committee de l'association en 1888 et en assura brièvement la présidence.

11 Le positionnement des Home Rulers écossais, qui se définissaient à la fois comme nationalistes et unionistes, peut sembler paradoxal. Ce nationalisme unioniste combinait deux forces qui, dans bien des cas, sont antagonistes. Il est difficile a priori d'affirmer une indépendance envers une structure centrale et de revendiquer l'appartenance à cette même structure. Or, dans le contexte du Home Rule écossais, une identité nationale forte se conjuguait avec une identité collective tout aussi forte. Les Home Rulers estimaient que l'Union pouvait être sérieusement menacée si des réformes constitutionnelles significatives n'étaient pas mises en œuvre. En militant pour l'obtention d'une autonomie accrue, ils se considéraient comme les authentiques défenseurs de l'Union: "Those who advocate such a policy (Scottish Home Rule) are the true Unionists while those who oppose it are really separatists. ${ }^{8}$

\section{La Scottish Home Rule Association}

12 La Scottish Home Rule Association vit le jour en mai 1886, un mois après l'introduction du Home Rule irlandais à la Chambre des communes. Les objectifs de l'association furent définis dans un document publié en 1887 :

A. To secure to the Government of Scotland, in the same degree as it is present possessed by the Imperial Government, the control of her Civil servants, Judges, and other officials, with the exception of those engaged in the Military, Naval and Diplomatic Services, and in collecting Imperial Revenue.

B. To promote the establishment of a Legislature sitting in Scotland, with full control over all purely Scottish questions, and with an Executive Government responsible to it and the Crown.

C To maintain the integrity of the Empire, and secure that the voice of Scotland shall be heard in the Imperial Parliament as fully as at present when discussing Imperial Affairs. ${ }^{9}$

13 La priorité de l'association était d'obtenir un statut spécial pour l'Écosse ; le Home Rule pour l'Irlande n'était envisageable que si l'équivalent pour l'Écosse pouvait être garanti. L'association se livra à un véritable travail de propagande : elle publia un grand nombre d'opuscules, envoya régulièrement des lettres aux journaux et contacta les candidats aux élections législatives pour leur demander de se déclarer favorables au Home Rule pour l'Écosse. L'association ne cessa de rappeler que le Parlement britannique ne consacrait qu'un temps extrêmement limité aux questions spécifiquement écossaises : "An hour or two in the small hours of the morning, three or four times a session, with MPs from England not appearing in the House until the Division Bell sounded and then they would vote along Party lines . ${ }^{10}$ En dépit de ses efforts, l'association ne parvint pas à convaincre les députés libéraux anglais de l'importance de la question. 


\section{La Young Scots' Society}

14 La Young Scots' Society, créée en 1900, était composée de libéraux qui tentèrent d'insuffler une nouvelle dynamique à un parti qui avait connu une défaite historique lors des élections de 1900. La société, bien qu'indépendante du parti libéral, lui était profondément liée. Elle compta jusqu'à 3500 membres en 1911 répartis en 56 antennes sur l'ensemble du territoire écossais. Pour les Young Scots, seul un parlement écossais pourrait prendre le temps nécessaire pour débattre des questions écossaises, ce qui impliquait une refonte complète du schéma constitutionnel britannique : une fédération construite autour d'un parlement impérial et regroupant les quatre nations des îles britanniques, disposant chacune de son propre parlement, constituait le système de gouvernement idéal. Un système fédéral présenterait l'avantage de répartir clairement les responsabilités et les fonctions entre les différentes structures :

A Federal system is the only possible and enduring solution of the Constitutional dif ficulty. Wherever Incorporation has been tried it has failed. Wherever Federalism has been tried it has proved success, allaying jealousy and racial animosity, and bringing about that strongest of all unions-the union of co-operation. ${ }^{11}$

Pour les Young Scots, il n'était nullement question de quitter l'Union mais au contraire de la renforcer et de l'améliorer. Ils en approuvaient le principe mais ils en critiquaient la structure et les modalités. La Société parvint à exercer une réelle influence dans le parti et joua un rôle déterminant dans les bons résultats électoraux des libéraux en Écosse lors des scrutins de 1906 et 1910. Les Young Scots continuèrent à rester actifs après la Première Guerre mondiale mais leur influence sur le parti libéral écossais ne fut plus aussi importante que pendant la période édouardienne.

\section{Les débats parlementaires sur le Home Rule écossais}

Le parlement britannique s'empara de la question du Home Rule pour l'Écosse pendant deux périodes bien distinctes, tout d'abord entre les années 1889 et 1895, période pendant laquelle une motion sur le Home Rule écossais fut présentée chaque année, et ensuite de 1910 à 1914. Les arguments et contre-arguments utilisés par les parlementaires au cours de ces vingt-cinq années présentent de grandes similitudes. Le seul élément véritablement novateur fut l'intégration en 1914 d'un amendement sur le droit de vote des femmes qui rencontra de fortes oppositions, y compris dans les rangs du parti libéral, certains députés indiquant qu'ils auraient voté le texte s'il n'avait pas contenu cet amendement.

17 Avant d'examiner les arguments pour et contre le Home Rule il convient d'essayer de préciser les contours du dispositif que les Home Rulers réclamaient de leurs vœux. La nouvelle architecture constitutionnelle de type fédéral reposait sur les points suivants :la création d'un parlement pour l'Écosse qui aurait comme fonction de traiter les questions spécifiquement écossaises; le maintien de l'Union entre les différentes composantes du Royaume-Uni ; le maintien du parlement impérial.

18 Les Home Rulers se rendirent compte que la création d'un parlement pour l'Écosse ne pouvait se faire sans la création en parallèle de parlements pour chacune des nations constitutives du Royaume-Uni, système qui devait prendre le nom de Home Rule all round. Le terme, qui fit son apparition au début des années 1880 , fait référence à la création de 
parlements spécifiques, non seulement pour l'Écosse et l'Irlande, mais aussi pour l'Angleterre et le pays de Galles. Il était difficile d'imaginer des parlements pour l'Irlande, l'Écosse et le pays de Galles sans que soit créé en parallèle un parlement défendant les intérêts de l'Angleterre. Dans le nouveau système, les parlements nationaux se verraient confier un certain nombre de domaines comme le commerce, l'agriculture, l'aide aux pauvres ou l'éducation alors que le parlement impérial conserverait les compétences essentielles dont le député d'Aberdeenshire Eastern, William Henry Cowan, donna la liste lors des débats de 1913 :

I will run over a list, which comprises most of the matters which we leave entirely to the Imperial Parliament. Everything affecting the Crown, peace, war, foreign affairs, national defence, naturalisation and domicile, trade marks, Scottish lighthouses, coinage, weights and measures, external trade, postal service, public loans to Scotland before the passing of the Act, and the collection of Imperial taxes. All those will remain in the full control of the Imperial Parliament with which the Scottish Parliament will have nothing to do and surely we have reserved a large measure of the activities of the Imperial Parliament. ${ }^{12}$

\section{Pourquoi les députés écossais réclamaient-ils le Home Rule?}

Il faut tout d'abord noter que la fin du XIX $\mathrm{X}^{\mathrm{e}}$ siècle correspondit à une période de centralisation accrue qui renforça les pouvoirs du gouvernement au détriment des instances locales. Le droit commercial anglais s'était imposé dans l'ensemble du Royaume-Uni même si le droit spécifique écossais continuait à prévaloir dans d'autres domaines. Nombre d'Écossais considérèrent que la loi sur l'Education écossaise de 1872 avait été trop influencée par la loi adoptée pour l'Angleterre deux ans plus tôt. Ces différentes mesures étaient perçues par un nombre croissant d'Écossais comme autant de tentatives d'anglicisation de l'Écosse. C'est ce que déplora William Henry Cowan lors des débats de 1913 :

In the early seventies this Scottish Department was transferred to London. That was a gratuitous insult to the nation, which had its own national and democratic system of education before England ever dreamt of educating her people at all, and if Scotland has not fully maintained her lead during the forty years since that transfer we must attribute it to this attempt to Anglicise Scotland, and that that attempt has largely failed, as it has, is one of the strongest evidences of the vitality of Scottish nationality. ${ }^{13}$

Une autre raison essentielle est à mentionner pour expliquer l'intérêt manifesté par une partie des hommes politiques écossais pour le Home Rule, celle du Home Rule irlandais. On peut sans conteste affirmer que le mouvement qui se développa à la fin du XIX siècle en faveur d'un Home Rule écossais se forgea en grande partie en réaction à la question du Home Rule irlandais. La corrélation entre les deux Home Rules fut explicitement mentionnée dans chacun des débats parlementaires. Les partisans du Home Rule écossais reconnaissaient que les Irlandais avaient toute légitimité à demander un parlement spécifique en raison de la manière dont leur nation avait été traitée par le gouvernement britannique ${ }^{14}$. Cependant, ils affirmaient avec force que l'Irlande ne pouvait pas bénéficier d'un traitement préférentiel. Nombreux furent les députés écossais à souligner que le temps passé à débattre de la question irlandaise réduisait considérablement le temps consacré aux questions écossaises. Si l'Irlande devait obtenir un nouveau statut au sein de l'Union, il était impensable que ce ne soit pas le cas aussi pour l'Écosse. La seule question était de savoir si les deux processus devaient se dérouler simultanément ou consécutivement. Certains, à l'image de Ronald Munro-Ferguson, député libéral de Leith 
Burghs et corédacteur de la motion de 1912, estimaient que le processus de dévolution devait se dérouler en plusieurs étapes : «Irish Home Rule is a part of Parliamentary necessity, and the first part of a general scheme of devolution of powers to be consecutively implemented by the same Government. " ${ }^{15} D$ 'autres députés, au contraire, ne voyaient aucune raison à ce que les deux processus soient dissociés :

We are told that Scotland ought not to stand in the way; that we ought to do all we can to get the Bill passed for Ireland granting Irish Home Rule; and that then it will be far easier, for the first step will be taken, to give Home Rule to Scotland. But I think it would be much easier to give Home Rule all round than to proceed by different Bills for one fraction after another. ${ }^{16}$

\section{L'Écosse, l'Union et l'empire}

Pour les partisans du Home Rule, tout comme pour ceux qui s'y opposaient, l'empire constituait le socle et le fondement cardinal de l'architecture constitutionnelle britannique. Il n'était nullement question pour les défenseurs du Home Rule de porter atteinte, de quelque manière que ce soit, à l'intégrité de l'empire. Les partisans du Home Rule se faisaient fort, d'ailleurs, de rappeler que l'Écosse avait pris une part déterminante dans le développement de l'empire. Thomas McKinnon Wood, député libéral de la circonscription de Glasgow St Rollox et ministre pour l'Écosse de 1912 à 1916, résuma avec conviction le profond sentiment d'appartenance des Écossais à l'empire :

No one is wanting to interfere with the Imperial Union of the country. None of us would be advocating Home Rule-I certainly should not-if I thought it was to diminish by one jot or tittle our share in the Imperial management of the Empire in which we have as great a concern as Englishmen, and in which we have done our part. $^{17}$

L'Union fut, elle aussi, largement évoquée au cours des débats parlementaires. Il est intéressant de noter que la question de l'appartenance à l'Union fut utilisée à la fois par les défenseurs et les opposants au Home Rule. Pour les Home Rulers, il était inconcevable de quitter l'Union. Même si certains députés estimaient que l'Union avait eu des conséquences bénéfiques pour l'Écosse, d'autres n'en reconnaissaient pas moins ses limites en considérant que le processus avait davantage relevé de l'absorption politique que d'une authentique union entre deux entités égales ou en soulignant le fait que l'Union avait porté atteinte à l'indépendance de l'Écosse ${ }^{18}$. Les Home Rulers insistèrent de façon presque obsessionnelle sur le fait que leur revendication d'autonomie n'était en rien à interpréter comme un désir de séparation de l'Union. Leur désir d'autonomie pouvait pleinement s'épanouir dans le cadre existant de l'Union, position que résuma parfaitement Gavin Clark lorsqu'il présenta sa résolution en avril 1889:

In moving the Resolution that stands in my name let me say at once that that Resolution does not mean separation. I have no desire to repeal the Union between England and Scotland, and I think that Union has been mutually beneficial-a good thing for Scotland, but a better thing for England. [...] I trust that in the consideration of Home Rule propositions we shall still preserve intact the great Anglo-Saxon Union that has done so much for civilization, that has so much still to do. ${ }^{19}$

\section{Les dysfonctionnements du parlement}

Le parlement britannique fonctionnait mal : tel fut l'un des arguments principaux mis en avant par les Home Rulers pour justifier leur demande. Par manque de temps, le parlement 
ne parvenait pas à traiter les questions spécifiques à l'Écosse, ce qui avait comme conséquence de reporter les réformes indispensables à l'amélioration des conditions de vie des citoyens écossais. En 1889, les Home Rulers mentionnèrent plusieurs textes de lois qui ne purent être examinés faute de temps, notamment le Public Health and Police Bill ou le Scotch Universities Bill. Lors du débat de 1912, William Chapple indiqua qu'au cours des onze années précédentes, le Parlement avait adopté 523 lois dont 44 portaient sur l'Écosse ${ }^{20}$. Les Écossais, aux dires des Home Rulers, avaient donc toutes les raisons de se sentir négligés ou oubliés par le parlement. Les Home Rulers mentionnèrent également la question de la légitimité des députés à se prononcer sur des dossiers qui ne les intéressaient ou ne les concernaient pas. Lors des débats de 1913, Thomas Power O'Connor, député nationaliste irlandais de Liverpool, résuma l'opinion des Home Rulers sur ce point :

Affairs in Scotland are discussed and decided, not by the local knowledge of Scotsmen, but by the ignorance of Englishmen and Irishmen and Welshmen; and that is what goes on all round. Irish affairs are discussed and decided by English ignorance. Scottish affairs are discussed and decided by English or Irish or Welsh ignorance. Welsh affairs are discussed and decided by English or Scottish or Irish ignorance, and English internal affairs are decided not by English knowledge, but by Irish or Scottish or Welsh ignorance. ${ }^{21}$

L'autre élément sur lequel insistaient les Home Rulers fut celui du manque de connaissances des députés non-écossais. Il leur fut régulièrement reproché d'ignorer les fondements du système juridique écossais et donc de se prononcer sur des sujets qu'ils ne maitrisaient pas, point qui fut notamment soulevé par Ian Macpherson, député libéral de Ross and Cromarty, lors de l'examen du texte de loi de 1914 :

Its [Scotland's] laws are its own, and its legal system is the most perfect if it is also one of the most difficult in the world. There could be nothing more ludicrous than to hear English Members discussing "hamesucken, multiplepoinding, blench dispositions, Emphyteusis, stillicide, and ad avizandum."22

Les Home Rulers écossais déploraient également le manque d'assiduité de leurs collègues quand des questions écossaises étaient à l'ordre du jour et regrettaient qu'ils ne fassent leur apparition qu'au moment des votes. L'ensemble de ces critiques justifiait pleinement que soit créé un parlement traitant des affaires spécifiquement écossaises. Le premier avantage d'une telle mesure serait de décharger le parlement impérial de questions régionales ou locales ${ }^{23}$. Elle permettrait également d'accorder le temps nécessaire à l'examen des lois traitant de questions spécifiques à l'Écosse. En résumé, l'architecture du système politique britannique aurait tout à gagner de la création de parlements nationaux.

\section{Les autres arguments des Home Rulers}

Outre la centralisation croissante, le déséquilibre avec l'Irlande et les dysfonctionnements du parlement, les tenants du Home Rule firent appel à d'autres arguments plus ou moins récurrents. C'est ainsi qu'ils mentionnèrent avec régularité les interventions parlementaires de William Gladstone. En 1912, William Chapple, député libéral de Stirlingshire, cita un extrait d'une intervention de William Gladstone datant de 1889 dans laquelle Gladstone, alors dans l'opposition, s'exprimait sur le principe de la dévolution :

I hold that all judicious devolution which hands over to subordinate bodies duties for which they are better qualified by local knowledge, and which at the same time sets free the hands of Parliament for the pursuit of its proper business, does not 
weaken it but strengthens it, gives vitality to it, and makes the people more than ever disposed to support the supremacy of Parliament. ${ }^{24}$ 1910 et 1914. Les Home Rulers, sans doute influencés par les Young Scots, prirent des positions plus radicales : les indispensables réformes destinées à améliorer les conditions d'existence de la population écossaise ne pourraient être prises que par un parlement écossais.

\section{La spécificité écossaise ou l'affirmation de la différence}

31 Dans toute revendication nationale figurent des rappels à l'histoire de la nation et aux grandes figures historiques du passé. Cependant, les débats parlementaires sur le Home Rule écossais contiennent peu, voire très peu, de références au passé de la nation écossaise et à ses figures légendaires. Les remarques formulées par Eugene Wason, député libéral de Clackmannanshire and Kinrossshire, en 1913 et 1914 constituent une exception notoire. Dans son intervention de 1914, Eugene Wason mentionna par exemple la bataille de Bannockburn, événement emblématique du combat de l'Écosse pour l'indépendance :

I am going to give a quotation from William Earl of Douglas, in the year 1385:- "The Scottish people would endure pillage, and they would endure famine and every other extremity of war, but they will not endure an English master." That is our 
position to-day, and I may remind the House that this year is the six-hundredth anniversary of Bannockburn. ${ }^{27}$

Les Home Rulers souhaitaient avant tout marquer leur différence par rapport à l'Angleterre et c'est ainsi qu'ils protestèrent vigoureusement contre l'utilisation abusive du terme Angleterre pour désigner l'Écosse : l'Écosse se refusait à être diluée dans une entité générique anglaise, ce que rappela avec force Eugene Wason: "We decline to be considered in Scotland as a province of England. We decline that entirely. " ${ }^{28}$ Les Home Rulers estimaient, d'ailleurs, que la nation écossaise (la nation la plus démocratique au monde, d'après Gavin $\operatorname{Clark}^{29}$ ), n'avait rien à envier à son voisin anglais, bien au contraire. Certains d'entre eux, comme Daniel Holmes, député libéral de Govan, n'hésitèrent pas à insister sur la supériorité de l'Écosse sur l'Angleterre dans des domaines aussi divers que ceux de l'éducation, de la loi ou de la religion ${ }^{30}$. Une Union harmonieuse entre des nations fortes, fières de leur passé et de leur appartenance à l'empire, tel était le message que ne cessèrent de mettre en avant les partisans du Home Rule :

Scottish nationalism is not a question of party. It is not narrow; it is not embittered; it is not the product of mere semi-insular pride. Strong as is our attachment to our native country, its literature, its history, and its traditions, the strength of that attachment has not lessened but increased that broader side of the national spirit which glories in the inheritance and the continuance of an Empire which has come down to us largely through the wisdom, the powers, and the statesmenship of our kinsmen who have gone before. ${ }^{31}$

\section{L'opposition au Home Rule}

En guise de réponses aux arguments développés par les Home Rulers, les unionistes indiquèrent tout d'abord que les contextes irlandais et écossais n'étaient en rien comparables. L'Irlande avait été opprimée et négligée par le Parlement britannique et méritait donc une attention radicalement différente ${ }^{32}$. Même ceux qui étaient opposés au Home Rule irlandais estimaient que les Irlandais avaient, contrairement aux Écossais, une certaine légitimité à revendiquer un parlement spécifique pour leur nation :

I say, without the slightest hesitation, that while in regard to Ireland I thoroughly understand the feeling and recognise that it is a feeling of long growth, which has a real force in the minds of the people, this agitation in Scotland is of a purely hothouse breed, and if it were to become necessary to give Home Rule to Ireland, which I hope it never will, surely it would be a great misfortune to inflict it on Scotland simply to create an excuse for giving it to another island. What can Scotland possibly gain by a change of this kind? ${ }^{33}$

Le Home Rule risquait de porter un coup fatal à l'Union: tel fut l'argument principal régulièrement utilisé par les intervenants lors des différents débats. Le Home Rule n'apporterait que division et chaos à un système qui fonctionnait parfaitement et qui n'avait donc nul besoin d'être modifié. Les unionistes, de surcroit, ne cessèrent de mettre en avant les avantages que l'Écosse avait retirés de son appartenance à l'Union :

Absorption was an absolute necessity, and, as the event has proved, was a magnificent advantage to Scotland. What did she exchange for it? She exchanged for her various disadvantages an undivided partnership in a vast Imperial heritage which has been to her of the most enormous advantage, and which has given to her sons the opportunity and privilege which otherwise they would not have had; and which has given Scotland the opportunity of increasing her commercial position and of establishing it on a firm footing. ${ }^{34}$ 
Certains députés considéraient l'Union comme une étape fondamentale dans l'histoire de l'Écosse : sans l'Union, l'Écosse serait restée une nation mineure, rongée par les conflits et les rivalités et n'aurait pas pu atteindre son remarquable niveau de développement. Les défenseurs de l'Union considéraient que la nationalité écossaise avait pu s'affirmer et s'épanouir dans l'Union sans la moindre entrave et insistaient sur les innombrables bénéfices que l'Union avait apportés aux Écossais.

D'autres arguments furent de nature plus pragmatique. Les opposants au Home Rule firent ainsi remarquer que l'Écosse n'était pas la seule à souffrir de la surcharge de travail parlementaire. Ils notèrent également qu'il était difficile de trouver des candidats écossais pour un seul parlement: il serait donc encore plus difficile de trouver des candidats écossais pour deux parlements distincts. La création de parlements nationaux engendrerait, de surcroît, un coût supplémentaire non seulement pour le Royaume-Uni mais aussi pour chacune des quatre nations : aux yeux des opposants au Home Rule, il était peu probable que les citoyens britanniques soient prêts à financer ce nouveau dispositif. L'opposition au Home Rule se manifesta également par la mention des problèmes qui pourraient apparaître à la suite de la création de parlements nationaux. Comment pouvait-on imaginer un système fédéral construit autour d'un principe de décentralisation qui oublierait d'accorder l'autonomie à certaines parties du RoyaumeUni ? Arthur Balfour fut sans doute l'un des députés à pousser cette réflexion le plus loin. Pour lui, engager le processus de Home Rule, c'était ouvrir une boîte de Pandore constitutionnelle :

Whatever Ireland asks for in principle, Scotland has the right to ask for in principle. I accept that entirely. And whatever Ireland has a right to ask for in principle, Middlesex has a right to ask for in principle. And whatever Middlesex asks for, Yorkshire has a right to ask for. ${ }^{35}$

Certains députés abordèrent la question du périmètre des compétences qui seraient accordées à ces nouvelles structures. Quel que soit le schéma retenu, il y aurait inévitablement des conflits entre les différentes structures: un parlement doté de compétences réduites et locales empiéterait sur les compétences des collectivités locales et un parlement disposant de pouvoirs plus étendus empiéterait sur les compétences du parlement impérial. La question de la coloration politique différente des parlements impérial et nationaux pourrait également se poser, ce qui aurait comme conséquence de créer des tensions et de nuire au bon fonctionnement de la démocratie britannique.

\section{Les raisons de l'échec du Home Rule écossais}

Le débat sur le Home Rule écossais donna l'opportunité à la représentation parlementaire de s'interroger sur la forme que pouvait revêtir l'architecture constitutionnelle d'un pays regroupant plusieurs nations différentes. Les concepts de décentralisation, de dévolution et de fédéralisme furent abondamment discutés et analysés. La question fondamentale de l'appartenance de l'Écosse à l'Union fut largement commentée à la fois par les tenants du Home Rule, qui estimaient qu'un système fédéral permettrait de stabiliser et de consolider l'Union, et les opposants au Home Rule, qui pensaient qu'un tel dispositif serait une catastrophe pour l'Union. Comme cela a été précisé par ailleurs, lors des débats qui se déroulèrent sur une période de près de vingt-cinq années, les différents intervenants eurent recours à des arguments très similaires. Comment expliquer alors que le Home Rule , souvent présenté comme essentiel pour l'avenir de l'Écosse et soutenu par une majorité 
de députés écossais, ait été rejeté par le parlement britannique ? Il ne fait guère de doute que le contexte général joua en défaveur du Home Rule écossais : pendant les années précédant la Première Guerre mondiale, le gouvernement libéral dut faire face à une série de crises internes et internationales sans doute perçues comme bien plus importantes que la question de l'autonomie écossaise. On mentionnera, ensuite, la question de la loyauté des députés libéraux écossais qui, paradoxalement, joua en leur défaveur. Ce point fut notamment évoqué en 1893 par Robert Reid, député libéral de Dumfries ${ }^{36}$ et en 1914 par James Duncan Millar, député libéral de North East Lanarkshire, ce dernier remarquant que les Écossais étaient trop respectueux des lois pour obtenir ce que les autres obtenaient par la contestation violente et l'agitation perpétuelle ${ }^{37}$. Comme le laisse suggérer le nombre peu élevé de députés présents lors des débats consacrés au Home Rule écossais, le Parlement ne manifesta qu'un intérêt limité pour la question. Tous ces éléments n'apportent cependant qu'une réponse partielle à l'échec du Home Rule écossais. Il est, en conséquence, légitime de se demander si le Home Rule constitua une question prioritaire pour l'ensemble des Écossais, ce que les Home Rulers ne cessèrent, pourtant, d'affirmer. Les opposants au Home Rule, à l'image du député unioniste William Watson, insistèrent sur le manque d'appétence des Écossais pour l'autonomie législative :

We were told last year that the question of Home Rule for Scotland was the most absorbing political question after the land question. If that is so, all I can say is that it certainly absorbed very little of the five weeks during which I was recently engaged in an election in Scotland, for I never mentioned it myself. I was only asked questions about it twice, and since then I have heard nothing more of it. Personally, I have not come across any great desire in Scotland for Home Rule. One knows, of course, from reading the newspapers, that the Young Scots Society are very keen for it, and are working very hard for it, but, as to the result of that work, I, personally at any rate, have seen precious little result. ${ }^{38}$

39 Vingt ans plus tôt, Charles Pearson, député conservateur d'Edinburgh and St. Andrews Universities, avait formulé une opinion similaire quand il avait affirmé que le parti libéral considérait la question comme secondaire, l'opinion publique écossaise ne manifestant que peu d'intérêt pour le mouvement en faveur du Home Rule ${ }^{39}$. Ce manque d'intérêt semble être confirmé par le fait que les Home Rulers candidats aux élections législatives ne mentionnèrent que très rarement le Home Rule dans leurs réunions ou leurs plateformes électorales. Les interventions du marquis de Tullibardine, député conservateur de Perthshire West, lors des débats de 1912 et de 1914, sont, à ce titre, particulièrement éclairantes. C'est ainsi que lors de la session de 1914, il cita les noms de plusieurs candidats du parti libéral ouvertement favorables au Home Rule, dont Thomas McKinnon Wood, le ministre pour l'Écosse, qui, pourtant, seraient restés silencieux sur la question ${ }^{40}$.

Au nombre des autres raisons qui pourraient expliquer l'échec du Home Rule écossais se doivent de figurer en bonne place les attitudes des dirigeants du parti libéral. On soulignera notamment le peu d'enthousiasme du comte de Rosebery, premier ministre de 1894 à 1895 , et surtout l'ambivalence des prises de position de William Gladstone, figure emblématique du parti qui pourtant se déclara favorable au processus de dévolution, du moins en principe. Cette ambivalence est parfaitement illustrée par le passage suivant, extrait de son intervention lors des débats de 1890 :

It is our duty to admit whatever facts appear to stand in the clear light of the evidence of facts, but above all to rush to no rash, unfounded, blind conclusions; but rather to say, "We will wait for further light and for the further maturity of this question in the minds of the people of Scotland, rather than run the slightest risk of misleading her, and possibly even of disturbing the country, as well as impeding the 
course of the public business by the adoption of propositions upon which we as yet do not possess, and do not even see in our own mind the means of leading to a satisfactory conclusion." 41

41 Ce fut Gavin Clark, le député libéral de Caithness, qui, lors de ce même débat, résuma le mieux la position de William Gladstone :

The question of Scotch Home Rule has not been raised on account of our admiration for the right hon. Member for Mid Lothian (Mr. Gladstone), or in consequence of any feeling in reference to him, because in this matter the right hon. Gentleman has always been coldly neutral. It has simply grown up from dissatisfaction which exists in Scotland in regard to the treatment of Scotch affairs. ${ }^{42}$

Il ne fait aucun doute que cette attitude de «froide neutralité » constitua un handicap majeur pour les Home Rulers écossais.

\section{Conclusion}

La présente étude des débats sur le Home Rule écossais qui eurent lieu au Parlement entre 1889 et 1914 a permis de comprendre comment les Home Rulers tentèrent de persuader la classe politique britannique du bien-fondé de leur cause. Pendant cette période ils eurent recours aux mêmes arguments, insistant sur le fait que qu'un système fédéral et donc un parlement écossais permettraient enfin de traiter les questions qui avaient été négligées par le parlement britannique. Bien que leurs arguments fussent largement et méthodiquement diffusés, ils ne réussirent pas à convaincre les citoyens écossais. Leurs différentes tentatives se soldèrent par des échecs, dus en grande partie à un manque d'adhésion et de soutien d'une majorité de parlementaires. Sans aller jusqu'à partager l'opinion de Vernon Bogdanor, pour lequel les textes de loi sur le Home Rule écossais ne constituèrent qu'une forme de rituel des élus libéraux et travaillistes qui se sentaient dans l'obligation d'affirmer que les droits des Écossais étaient identiques à ceux des Irlandais ${ }^{43}$, il est possible de penser que l'opinion publique écossaise avait compris que le Home Rule écossais n'était pas un phénomène endogène et que le mouvement pour l'instauration d'un parlement écossais n'avait pris forme qu'en réaction au Home Rule irlandais.

\section{Bibliographie sélective}

\section{Sources primaires}

Hansard, Parliamentary Debates, https://hansard.parliament.uk/ 


\section{Sources secondaires}

Bogdanor, Vernon, Devolution in the United Kingdom (Oxford, Oxford University Press, 1999).

Brand, Jack, The National Movement in Scotland (Londres, Routledge et Kegan Paul, 1978).

Cook, Anthony, Donnachie I., MacSween A., Whately Ch. (dir.), Modern Scottish History 1717 to the Present, vol. 5 Major Documents (East Linton, Tuckwell Press, 1998).

Devine, Thomas Martin, The Scottish Nation 1700-2000(Harmondsworth, Penguin, 2000 [1999]).

Devine, Thomas Martin, Wormald J. (dir.), The Oxford Handbook of Modern Scottish History (Oxford, Oxford University Press, 2012).

Devine, Thomas Martin, Independence or Union Scotland's Past and Scotland's Present (Londres, Allen Lane, 2016).

Duchein, Michel, Histoire de l'Écosse (Paris, Fayard, 1998).

Finlay, Richard, A Partnership for Good: Scottish Politics and the Union since 1880 (Édimbourg, John Donald, 1997).

Kennedy, James, “ "Contrasting Liberal Nationalists": The Young Scots' Society and the Ligue Nationaliste Canadienne", Nationalism and Ethnic Politics, 13:1 (2007), pp. 39-70.

Kennedy, James, Liberal Nationalisms: Empire, State, and Civil Society in Scotland and Quebec (Montréal, Québec, McGill-Queen's Press, 2013).

Hutchison, I.G.C., Scottish Politics in the Twentieth Century (Basingstoke, Palgrave, 2001).

Lynch, Michael, Scotland A New History (Londres, Pimlico, 1991).

Morton, Graeme, “The First Home Rule Movement in Scotland, 1886 to 1918”, in H.T. Dickinson and Michael Lynch (dir.), The Challenge to Westminster: Sovereignty, Devolution and Independence (East Linton, Tuckwell Press, 2000), p. 113-122.

O'Brien, Richard Barry, The Life of Charles Stewart Parnell 1846-1891, vol. 2 (Londres, Smith, Elder et co, 1898).

\section{NOTES}

1. Thomas Martin Devine, Independence or Union Scotland's Past and Scotland's Present (Londres, Allen Lane, 2016), p. 86.

2. On pourra mentionner les ouvrages suivants: John Hill Burton, The Scot Abroad (Edimbourg, W. Blackwood \& Sons, 1864) et W.J. Rattray, The Scot in British North America, Toronto, 1880.

3. Andrew Dewar Gibb, Scotland in Eclipse (Londres, Humphrey Toulmin, 1930), cité dans Devine, Independence or Union Scotland's Past, p. 99.

4. Cité dans Devine, Independence or Union Scotland's Past., p. 91.

5. L'expression est de Devine,in ibid., p. 88.

6. William Gladstone, cité dans Richard Barry O'Brien, The Life of Charles Stewart Parnell 1846-1891, vol.2 (Londres, Smith, Elder \& Co., 1898), p. 211.

7. Cité dans Richard Finlay, A Partnership for Good: Scottish Politics and the Union since 1880 (Édimbourg, John Donald, 1997), p. 48.

8. Extrait d'un article de la Scottish Review de 1888, cité dans Finlay, A Partnership for Good, p. 48. 
9. An $A B C$ on Home Rule in The Union of 1707 Viewed Financially, and Scotland and Home Rule, cité dans Graeme Morton, "The First Home Rule Movement in Scotland, 1886 to 1918”, in H.T. Dickinson and Michael Lynch (dir.), The Challenge to Westminster: Sovereignty, Devolution and Independence (East Linton, Tuckwell Press, 2000), p. 116-117.

10. Article du Perthshire Courier du 7 avril 1896, cité dans Morton, "The First Home Rule Movement in Scotland", p.119.

11. Cité dans James Kennedy, "Contrasting Liberal Nationalists: The Young Scots' Society and the Ligue Nationaliste Canadienne", Nationalism and Ethnic Politics, 13:1 (2007), p. 51.

12. William Cowan, 30 mai 1913, Hansard, Parliamentary Debates, vol. 53, col. 481.

13. Ibid., col. 478 .

14. Voir notamment l'intervention de Gavin Clark, député libéral de Caithness, 19 février 1890, in ibid., vol. 341, col. 693.

15. Ronald Munro-Ferguson, 28 février 1912, in ibid., vol. 34, col. 1456.

16. Gavin Clark, 6 mars 1891, in ibid., vol. 351, col. 444.

17. Thomas McKinnon Wood, 15 mai 1914, in ibid., vol. 62, col. 1546.

18. Voir notamment l'intervention de William Chapple, député libéral de Stirling, 28 février 1912, in ibid., vol. 34, cols. 1448-1449.

19. Gavin Clark, 9 avril 1889, in ibid., vol. 335, cols. 68-74.

20. William Chapple, 28 février 1912, in ibid., vol. 34, col. 1450.

21. Thomas Power O'Connor, 30 mai 1913, in ibid., vol. 53, cols. 513-514.

22. Ian Macpherson, 15 mai 1914, in ibid., vol. 62, col. 1473.

23. Voir Gavin Clark, 6 mars 1891, in ibid., vol. 351, col. 448.

24. William Gladstone, cité par William Chapple, 28 février 1912, in ibid., vol. 34, col. 1452.

25. William Chapple, 28 février 1912, in ibid., vol. 34, col. 1448.

26. Robert Cuninghame Graham, 9 avril 1889, in ibid.,, vol. 335, cols. 97-98.

27. Eugene Wason, 15 mai 1914, in ibid., vol. 62, col. 1504.

28. Eugene Wason, 30 mai 1913, in ibid, vol. 53, col. 500.

29. Gavin Clark, 6 mars 1891, in ibid., vol. 351, col. 441.

30. Daniel Holmes, 15 mai 1914, in ibid., vol. 62, col. 1533.

31. Ian Macpherson, 15 mai 1914, in ibid., vol. 62, col. 1468.

32. Voir notamment le discours de Donald Crawford, député de Lanarkshire, 9 avril 1889, in ibid., vol. 335 , col. 94 .

33. Andrew Bonar Law, 28 février 1912, in ibid., vol. 34, col 1487.

34. George Younger, 30 mai 1913, in ibid., vol. 53, col. 511.

35. Arthur Balfour, 9 avril 1889, in ibid., vol. 335, cols. 110-111.

36. Robert Reid, 23 juin 1893, in ibid., vol. 13, col. 1833.

37. James Duncan Millar, 15 mai 1914, in ibid., vol. 62, cols. 1515-1516.

38. William Watson, 15 mai 1914, in ibid., vol. 62, cols. 1495-1496.

39. Charles Pearson, 23 juin 1893, in ibid., vol. 13, col. 1856.

40. Marquis de Tullibardine, 15 mai 1914, in ibid., vol. 62, cols. 1509-1510.

41. William Gladstone, 19 février 1890, in ibid., vol. 341, col. 723.

42. Gavin Clark, 19 février 1890, in ibid, vol. 341, cols. 682-683.

43. Vernon Bogdanor, Devolution in the United Kingdom (Oxford, Oxford University Press, 1999), p. 120. 


\section{RÉSUMÉS}

Les débats parlementaires qui eurent lieu pour examiner les motions et propositions de lois sur le Home Rule écossais entre 1889 et 1914 constituent une remarquable source d'information sur les arguments qui furent avancés. L'étude des interventions des parlementaires permet de comprendre pourquoi le Home Rule s'imposa sur la scène politique écossaise à la fin du XIX ème siècle. L'article tente également de déterminer la place et l'importance du sentiment nationaliste écossais dans les revendications formulées par les Home Rulers. Une partie importante de cette étude est consacrée à l'analyse des contours du dispositif proposé par les Home Rulers et notamment l'articulation entre le parlement impérial et les parlements nationaux et leurs compétences respectives. Sont également étudiés les principaux arguments et contre arguments développés par les partisans et les opposants au Home Rule: la corrélation entre Home Rule irlandais et Home Rule écossais ainsi que la question fondamentale de l'Union, préservée pour les uns et menacée pour les autres, figurent au centre de cette analyse. La conclusion de l'article mentionne certaines des raisons pouvant expliquer l'échec des Home Rulers.

The parliamentary debates inspired by the introduction of motions and bills in favour of Scottish Home Rule between 1889 and 1914 are a remarkable source of information to assess the arguments that were put forward in favour and against Home Rule. Studying these debates allows to understand why the question of Home Rule came to dominate Scottish politics towards the end of the nineteenth century. This article also attempts to determine the weight of nationalism in the Scottish claims and to analyse the ins and outs of the schemes proposed by the Scottish Home Rulers - notably the way power was meant to be shared between the Imperial Parliament and the local parliaments. The main arguments and counter-arguments that were used respectively by the supporters and opponents of Scottish Home Rule will be examined, which will lead us to discuss the correlation between Irish Home Rule and Scottish Home Rule. The important question of the Scottish Union will also be focused on: some believed Scottish selfgovernment was compatible with the preservation of the Union while others believed Home Rule threatened this Union. The article concludes by highlighting some of the reasons that may explain the ultimate failure of Scottish Home Rulers to obtain self-government for Scotland.

\section{INDEX}

Mots-clés : Home Rule écossais, Home Rule irlandais, parlement, nationalisme, Union

Keywords : Scottish Home Rule, Irish Home Rule, parliament, nationalism, Union

\section{AUTEUR}

\section{CHRISTIAN AUER}

Professeur émérite à l'université de Strasbourg et membre de l'EA 2325 (SEARCH), Christian Auer est spécialiste d'études britanniques et écossaises et a notamment travaillé sur l'histoire politique, économique, sociale et culturelle des Hautes Terres d'Ecosse au 19ème siècle et sur 
l'implication des femmes dans la vie politique écossaise pendant la période victorienne. Ses publications les plus récentes incluent Improvement, pauvreté, évictions et émigration dans la presse d'Inverness de 1845 à 1855 (Paris, Editions Publibook, 2004); Luttes et résistances des femmes écossaises, 1838-1915 (Paris, L'Harmattan, Collection Des idées et des femmes, 2013) ; et Scotland and the Scots 1707-2007, A Reader (Strasbourg: Presses Universitaires de Strasbourg, 2013).

Christian Auer is Professor emeritus at the University of Strasbourg, France. His research has focused on British and Scottish studies and notably the political, economic, social and cultural history of the Scottish Highlands in the 19th century, as well as women's involvement in Scottish politics during the Victorian era. His most recent publications include Improvement, pauvreté, évictions et émigration dans la presse d'Inverness de 1845 à 1855 (Paris, Editions Publibook, 2004); Luttes et résistances des femmes écossaises, 1838-1915 (Paris, L'Harmattan, Collection Des idées et des femmes, 2013); and Scotland and the Scots 1707-2007, A Reader (Strasbourg: Presses Universitaires de Strasbourg, 2013). 